\title{
Pengaruh Corporate Governance terhadap Efisiensi Bank Umum Syariah di Indonesia
}

\author{
Muhammad Jamil ${ }^{1}$, Teuku Muana Refi ${ }^{2}$ \\ 1,2 Akademi Keuangan Perbankan Nusantara, Aceh Timur, \\ Indonesia.
}

\begin{abstract}
Abstrak. Penelitian ini menganalisis bubungan fungsional antara efisiensi Bank Umum Syariab (BUS) dengan implementasi good corporate governance (GCG) sebagai sebagai predictor variabel. Menggunakan data panel 6 emiten BUS yang listing di Bursa Efek. Indonesia selama periode 2014-2018, model regresi panel pendekatan fixed effect digunakan untuk. menganalisis keterkaitan antar variabel. Penelitian membuktikan bahwa secara simultan implementasi GCG yang terdiri dari proporsi kepemilikan saham, ukuran komisaris dan komposisi komisaris berpengaruh signifikan terbadap efisiensi BUS. Secara parsial, proporsi kepemilikan saham dan komposisi komisaris berpengaruh positif dan signifikan, sebaliknya ukuran komisaris tidak berpengaruh signifikan terhadap efisiensi BUS.
\end{abstract}

Kata kunci: Efisiensi bank umum syariah, implementasi GCG dan Regresi Panel.

Abstract. This study analyzes the functional relationship between the efficiency of Islamic Commercial Banks (BUS) and the implementation of good corporate governance (GCG) as a variable predictor. Using panel dataset of 6 BUS listed on the Indonesia Stock Exchange during the 2014-2018 period, the fixed effect panel regression model was used to analyze the relationship between variables. This study proves that the simultaneous implementation of GCG consisting of the proportion of share ownership, size of board, and board composition bave a significant effect on the efficiency of BUS. Partially, the proportion of share ownership and the boad composition have a positive and significant effect, on the other hand, the board size has no significant effect on the efficiency of BUS.

Keywords: Efficiency of sharia commercial bank, implementation of GCG and panel regression. 


\section{Pendahuluan}

Bank Umum Syariah (BUS) merupakan salah satu bank umum yang hingga saat ini memegang peranan penting dalam pembangunan ekonomi Indonesia (Ikhsan et al., 2020). Sebagaimana halnya bank umum konvensional, keberadaan BUS juga sangat diminati oleh masyarakat umum dan para pelaku dunia usaha, terutama ketika mereka ingin memanfaatkan layanan pembiayaan. Kehadirannya di Bursa Efek Indonesia (BEI) merupakan salah satu bukti konkrit bahwa kepemilikan saham perusahaan perbankan tersebut tidak lagi berada pada sekelompok orang, tetapi sudah menjadi milik publik. Sebagai lembaga keuangan yang sebagian sahamnya telah dimiliki oleh masyarakat luas, dalam mencapai tujuan bisnisnya BUS juga membutuhkan adanya pengelolaan yang baik terutama dalam penentuan strategi dan kebijakan, baik yang berhubungan perspektif finansial maupun non finansial. Implementasi prinsip good corporate governance (GCG) diharapkan dapat membantu manajemen dalam mewujudkan efisiensi pengelolaan perusahaan guna mencapai tujuan pencapaian laba dan memenuhi pemegang saham (Silva \& Majluf, 2018).

Di antara sejumlah indikator implementasi GCG pada perusahaan perbankan, terkait dengan berkaitan dengan proporsi kepemilikan saham, ukuran/jumlah komisaris dan komposisi komisaris. Keterkaitan antara proporsi kepemilikan saham dengan efisiensi perusahaan disebabkan secara umum pemegang saham memiliki kepentingan dengan efisiensi perusahaan. Ketika sebagian besar saham perusahaan dimiliki oleh pihak internal, maka upaya untuk meningkatkan efisiensi perusahaan menjadi kepentingan internal perusahaan. Sehingga semakin besar porsi kepemilikan saham oleh pihak internal perusahaan akan mendorong manajemen untuk meningkatkan efisiensi perusahaan. Ukuran/jumlah komisaris juga dapat berpengaruh pada efisiensi. Beberapa peneliti sebelumnya merekomendasikan jumlah komisaris yang optimal mungkin dapat mengurangi pengaruh manajemen terhadap keputusan. Temuan penelitian Al-Najjar (2015) menyatakan terdapat hubungan negatif antara boardsize dengan efisiensi dan kinerja perusahaan. Ukuran komisaris yang relatif besar berimplikasi bahwa pengeluaran perusahaan dalam bentuk gaji komisaris juga meningkat. Hal inilah yang menyebabkan ukuran komisaris berkorelasi negatif dengan efisiensi perusahaan.

Selanjutnya komposisi komisaris (board composition) juga dapat berdampak pada efisiensi perusahaan. Komposisi komisaris yang dimaksudkan disini adalah adanya komisaris independen. Semakin besar proporsi komisaris independen berarti semakin baik komposisi komisaris. Krivogorsky (2016) dan Rebeiz \& Salameh (2016) menyatakan pentingnya direktur independen. Mereka menemukan bahwa terhadap hubungan positif antara efisiensi bank dengan proporsi non executive director yang independen. Efisiensi operasional BUS yang listing di BEI tentunya juga dapat dikaitkan dengan penerapan prinsip good corporate governance seperti dijelaskan di atas, yakni proporsi kepemilikan saham, jumlah komisaris dalam perusahaan dan komposisi dewan komisaris. Hasil penelitian awal terhadap data terkait mengindikasikan bahwa masing-masing perusahaan perbankan tersebut memiliki tingkat efisiensi yang berbeda satu sama lain. Efisiensi yang dimaksudkan dalam hal ini diukur dari perbandingan antara biaya operasional dengan pendapatan operasional (BOPO). Selain itu, penerapan corporate governance pada masingmasing perusahaan juga relatif berbeda, baik dilihat dari segi proporsi kepemilikan saham, jumlah komisaris dalam perusahaan maupun komposisi dewan komisaris. Karena itu, yang menjadi pertanyaan adalah, apakah efisiensi BUS yang terdaftar di Bursa Efek Indonesia terkait dengan tiga faktor tersebut. Penelitian ini bertujuan untuk menganalisis pengaruh tiga prinsip GCG tersebut dengan efisiensi bank umum syariah di Indonesia.

\section{Literature Review}

\section{Keterkaitan proporsi kepemilikan saham dan efisiensi bank umum}

Salah satu indikator penting implementasi prinsip GCG dalam perusahaan berkaitan dengan kepemilikan saham. Pola kepemilikan saham dapat dikatagorikan dalam kepemilikan pemerintah, manajerial dan kepemilikan institusional. Sejumlah kajian empiris mengenai signifikansi hubungan antara efisiensi perusahaan dengan kepemilikan saham 
memberikan hasil yang ambigu. Hasil penelitian Garcia-Meca \& Sa'nchez-Ballesta (2011) dan Perrini et al. (2018) menyimpulkan bahwa konsentrasi kepemilikan saham oleh perusahaan dapat meningkatkan efisiensi perusahaan. Argumen yang mendasari temuan tersebut adalah bahwa kepemilikan saham oleh perusahaan secara nyata mengurangi konflik keagenan antara manajemen dan pemilik perusahaan, dan kondisi tersebut pada gilirannya berdampak pada penurunan biaya pengawasan. Berbeda dengan temuan tersebut, sebelumnya penelitian Jiang et al. (2009) dan Boone et al. (2011) menyimpulkan adanya hubungan tidak searah antara kepemilikan saham oleh pihak internal dengan efisiensi kegiatan operasional perusahaan.

\section{Keterkaitan ukuran komisaris dan efisiensi bank umum}

Keberadaan komisaris sangat penting dalam mendorong adanya pengawasan terhadap jalannya perusahaan. Peningkatan jumlah komisaris mengindikasikan adanya peningkatan kebutuhan akan pengawasan (Klein, 2018). Apalagi ketika perusahaan ingin mengejar tujuan pertumbuhan, komisaris diyakini memiliki peran kunci dalam mendukung keberhasilan manajemen dalam mencapai tujuan tersebut. Komisaris memiliki tanggung jawab agar aset pemegang saham dapat dilindungi dengan baik sehingga mereka dapat terhindar dari kerugian (Bebeji et al., 2015). Karena itu, perusahaan dengan jumlah komisaris relatif besar mengindikasikan bahwa kebutuhan personil untuk mengawasi kegiatan manajemen semakin mencukupi, dan hal tersebut berdampak pada kehati-hatian manajemen dalam bekerja. Penelitian empiris yang dilakukan oleh Hsu \& Petchsakulwong (2010) di Thailand membuktikan bahwa peningkatan jumlah komisaris berdampak baik bagi efisiensi pengelolaan perusahaan. Sebelumnya, hasil kajian Zelenyuk \& Zheka (2006) juga memberikan kesimpulan yang sama, dimana ukuran komisaris secara signifikan meningkatkan efisiensi perusahaan.

\section{Keterkaitan komposisi komisaris dan efisiensi bank umum}

Dewan komisaris memiliki peran penting dalam pengelolaan perusahaan. Keberadaan mereka dapat mengawasi jajaran manajer dalam menjalankan kegiatan operasional perusahaan. Sejumlah temuan memberikan bukti empiris bahwa keberadaan komisaris independen dalam perusahaan berdampak pada perbaikan pengelolaan perusahaan oleh manajer (Choe \& Lee, 2013). Kehadiran komisaris independen dapat berkontribusi pada objektivitas dan independensi pengambilan keputusan penting dalam perusahaan. Objektivitas dan independensi pengambilan keputusan oleh jajaran direktur berdampak pada perbaikan pengelolaan perusahaan secara keseluruhan (Bozec \& Dia, 2015; Krivogorsky, 2016). Hasil kajian empiris yang dilakukan oleh Rebeiz \& Salameh (2016) juga membuktikan pentingnya komisaris independen dalam perusahaan.

Adanya pengaruh komisaris independen terhadap efisiensi perusahaan perbankan telah dibuktikan oleh sejumlah peneliti. De Haan \& Vlahu (2015) melakukan kajian literatur dengan cara mereview sejumlah hasil kajian terkait menyimpulkan bahwa peningkatan komisaris independen dalam suatu perusahaan berdampak pada penurunan biaya operasional sehingga efisiensi meningkat. Demikian pula halnya dengan hasil kajian Yamori et al. (2017) juga menyimpulkan bahwa eksistensi komisaris independen dengan segala independensi mereka dalam berkerja, dapat mendorong efisiensi pengelolaan perusahaan.

\section{Metodologi Penelitian}

Pada penelitian ini yang menjadi populasi adalah seluruh bank umum syariah di Indonesia. Sampel penelitian dibatasi hanya pada bank umum syariah yang terdaftar di BEI selama periode tahun 2014-2018, terdiri dari Bank Bukopin Syariah, Bank Danamon Syariah, Bank Permata Syariah, Bank BRI Syariah, Bank Tabungan Pensiunan Nasional Syariah dan Bank Panin Dubai Syariah. Data yang digunakan dalam penelitian ini adalah data primer yang diambil secara langsung dari laporan keuangan dan laporan tahunan bank umum syariah yang yang terdaftar di Bursa Efek Indonesia.

Variabel yang dioperasionalkan terdiri dari efisiensi operasional bank umum dan implementasi prinsip GCG. Pengukuran efisiensi menggunakan rasio biaya operasional 
terhadap pendapatan operasional. Implementasi prinsip GCG menggunakan tiga sub variabel terdiri dari proporsi kepemilikan saham oleh institusi/perusahaan, jumlah komisaris, dan komposisi komisaris. Proporsi kepemilikan saham dimaksud dihitung dengan rasio jumlah saham yang dimiliki oleh internal perusahaan dengan jumlah total saham secara keseluruhan. Jumlah komisaris adalah jumlah komisaris dalam perusahaan yang dihitung dengan satuan orang. Selanjutnya komposisi komisaris yang dimaksudkan dalam penelitian ini berkaitan dengan adanya tidaknya komisaris independent yang kemudian diukur dengan satuan persentase komisaris independent terhadap total komisaris.

Model analisis yang digunakan untuk memprediksi efisiensi bank umum dengan menggunakan tiga predictor variables di atas adalah regresi panel. Regresi panel merupakan peralatan statistik untuk menguji hubungan fungsional antar variabel ketika data yang dioperasionalkan adalah data panel, yakni gabungan antara data silang dan data time series (Amri, 2014; Muliadi, \& Amri, 2019a; Amri, 2020). Penggunaan regresi panel dalam menganalisis data panel juga didukung oleh sejumlah penelitian empiris (Amri, 2017; Amri, 2019; Muliadi, \& Amri, 2019b). Secara ekonometrik, penerapan regresi panel dalam penelitian ini seperti diformulasikan dalam persamaan 1.

$\mathrm{BOPO}_{\mathrm{it}}=\mathrm{a}+\mathrm{b}_{1} \mathrm{PKS}_{\mathrm{it}}+\mathrm{b}_{2} \mathrm{UK}_{\mathrm{it}}+\mathrm{b}_{3} \mathrm{KK}_{\mathrm{it}}$

\section{Dimana:}

BOPO $_{\text {it }}$ : Rasio biaya operasi terhadap pendapatan operasi emiten $i$ pada periode $t$, rasio ini dijadikan proxy dari efisiensi perusahaan.

$\mathrm{PKS}_{\text {it }} \quad$ : Proporsi kepemilikan saham emiten i pada periode $t$.

UK $_{\text {it }}$ : Ukuran komisaris emiten i pada periode $t$.

$\mathrm{KK}_{\mathrm{it}} \quad$ : Komposisi komisaris emiten i pada periode $\mathrm{t}$
Pengujian signifikansi pengaruh variabel independen terhadap rasio BOPO sebagai proxi negatif efisiensi perusahaan didasarkan pada nilai p-value yang dihasilkan melalui proses perhitungan statistik. Jika nilai p-value suatu variabel lebih kecil dari 0,05 berarti pada tingkat keyakinan 95\%, variabel tersebut berpengaruh signifikan terhadap efisiensi perusahaan. Sebaliknya, jika nilai p-value $>0,05$ bermakna bahwa secara statistik variabel tersebut tidak berpengaruh signifikan pada tingkat keyakinan yang sama.

\section{Hasil dan Pembahasan}

\section{Deskripsi Variabel dan Pemilihan Model Regresi}

Sebagaimana dijelaskan sebelumnya, pengukuran efisiensi bank umum dalam kajian ini menggunakan rasio biaya operasi dengan pendapatan operasi. Peningkatan rasio ini berarti terjadinya penurunan efisiensi. Sebaliknya, penurunan rasio ini mengindikasikan adanya perbaikan efisiensi. Selanjutnya proporsi kepemilikan saham yang dimaksudkan dalam kajian ini adalah persentase saham perusahaan perbankan yang dimiliki oleh internal perusahaan. Kemudian ukuran komisaris adalah total komisaris yang dimiliki oleh perusahaan, termasuk komisaris independent. Terakhir, komposisi komisaris merupakan persentase komisaris independent terhadap total dewan komisaris. Analisis terhadap data yang diperoleh melalui dokumentasi terhadap dokumen terkait menginformasikan bahwa efisiensi BUS relatif berbeda satu sama lain. Demikian pula halnya dengan proporsi kepemilikan saham oleh internal perusahaan, ukuran komisaris dan komposisi dewan komisaris. Melalui statistik deskriptif dapat digambarkan sejumlah parameter statistik seperti rata-rata, nilai maksimum dan minimum masing-masing variabel. Hasil pengolahan data menunjukkan rata-rata BOPO rasio sebesar $85,41 \%$ dengan nilai maksimum dan minum masing-masing sebesar $99,57 \%$ dan $62,40 \%$. Selanjutnya untuk variabel proporsi kepemilikan saham diperoleh nilai rata-rata sebesar $42,42 \%$ dengan nilai maksimum dan minimum masing-masing sebesar 57\% dan 31\%. Tabel 1 memperlihatkan hasil statistik deskriptif dan koefisien korelasi antar variabel. 
Tabel 1. Hasil Statistik Deskriptif

\begin{tabular}{l|c|c|c|c}
\hline \multicolumn{5}{c|}{ Statistik Deskriptif } \\
\hline Mean & $\begin{array}{c}\text { BOPO } \\
(\%)\end{array}$ & $\begin{array}{c}\text { Proporsi Kepemilikan } \\
\text { Saham (\%) }\end{array}$ & $\begin{array}{c}\text { Ukuran } \\
\text { Komisaris } \\
(\text { Orang })\end{array}$ & $\begin{array}{c}\text { Komposisi } \\
\text { Komisaris (\%) }\end{array}$ \\
\hline Maximum & 85,41 & 42,42 & 5 & 54,01 \\
\hline Minimum & 99,57 & 57,00 & 8 & 66,67 \\
\hline Jarque-Bera & 62,40 & 31,00 & 3 & 33,33 \\
\hline Probability & 2,87 & 3,227 & 4,415 & 1,597 \\
\hline Observations & 0,237 & 0,199 & 0,110 & 0,449 \\
\hline
\end{tabular}

Sumber: Data Sekunder (Diolah), 2020.

Penggunaan regresi panel dalam menguji dan menganalisis hubungan fungsional data panel meneyediakan tiga alternatif pendekatan. Ketiga pendekatan tersebut adah common effect, fixed effect dan dan random effect model. Pemilihan salah satu pendekatan yang dianggap menghasilkan estimasi terbaik memerlukan adanya uji statistik yakni Chow test dan Hausman test.
Seperti dalam tabel di atas, nilai p-value untuk dua jenis uji statistik baik Chow test maupun Haussman test lebih kecil dari 0,05. Karena itu, pendekatan regresi panel yang diyakini dapat memberikan hasil estimasi paling akurat adalah pendekatan fixed effect.

Tabel 2. Hasil Chow Test

\begin{tabular}{ccccc}
\hline Uji Efek & & Statistic & df & p-value \\
\hline Cross-Section & Cross-section F & 8,732 & $(5,27)$ & 0,000 \\
Fixed Effects & Cross-section Chi-square & 34,634 & 2 & 0,000 \\
\hline
\end{tabular}

Sumber: Data Sekunder (Diolah), 2020.

Penggunaan Chow test dimaksudkan untuk menentukan piliban terbaik antara common effect atau fixed effect. Selanjutnya Hausman test dimaksudkan untuk menentukan pilihan terbaik antara fixed atau random effect. Kedua pendekatan tersebut menggunakan nilai p-value yang dihasilkan melalui perhitungan statistik sebagai dasar pengambilan keputusan. Jika nilai $\mathrm{p}$-value yang dihasilkan oleh Chow test lebih kecil dari 0,05, maka model terbaik adalah fixed effect, dalam kondisi sebaliknya, pendekatan common effect dianggap menghasilkan estimasi terbaik. Selanjutnya jika nilai $p$-value yang dihasilkan oleh Haussman test lebih kecil dari 0,05, maka metode terbaik adalah fixed effect, dalam kondisi sebaliknya, random effect dianggap menghasilkan estimasi lebih akurat. Hasil uji statistik kedua pendekatan tersebut seperti ditunjukkan dalam tabel 2 dan 3.

\section{Analisis Pengaruh Implementasi GCG terhadap Efisiensi Bank Umum Syariah}

Hasil pengolahan data memberikan informasi statistik bahwa implementasi prinsip GCG berpengaruh negatif terhadap rasio BOBO bank umum syariah. Seperti dijelaskan sebelumnya, peningkatan rasio BOPO berarti terjadinya penurunan efisiensi. Dalam kondisi sebaliknya, efisiensi meningkat. Sehingga rasio tersebut sebenarnya merupakan proxi negatif dari pengukuran efisiensi bank umum. Adanya pengaruh negatif dapat diinterpretasikan bahwa semakin tinggi nilai tiga variabel yang dijadikan ukuran bagi implementasi prinsip GCG terdiri dari proporsi kepemilikan saham, ukuran komisaris dan komposisi dewan komisaris, semakin rendah rasio BOBO. Hal ini menginformasikan bahwa sebenarnya ketiga variabel tersebut berpengaruh positif terhadap efisiensi bank umum. Untuk lebih jelasnya

Tabel 3. Hasil Haussman Test

\begin{tabular}{|c|c|c|c|}
\hline Uji Efek & $\mathrm{X}^{2}$-Statistic & $\mathrm{df}$ & p-value \\
\hline Cross-Section Random Effects & 8,352 & 3 & 0,003 \\
\hline
\end{tabular}


ditunjukkan dalam Tabel 4.

Tabel 4. Ringkasan Hasil Regresi Panel

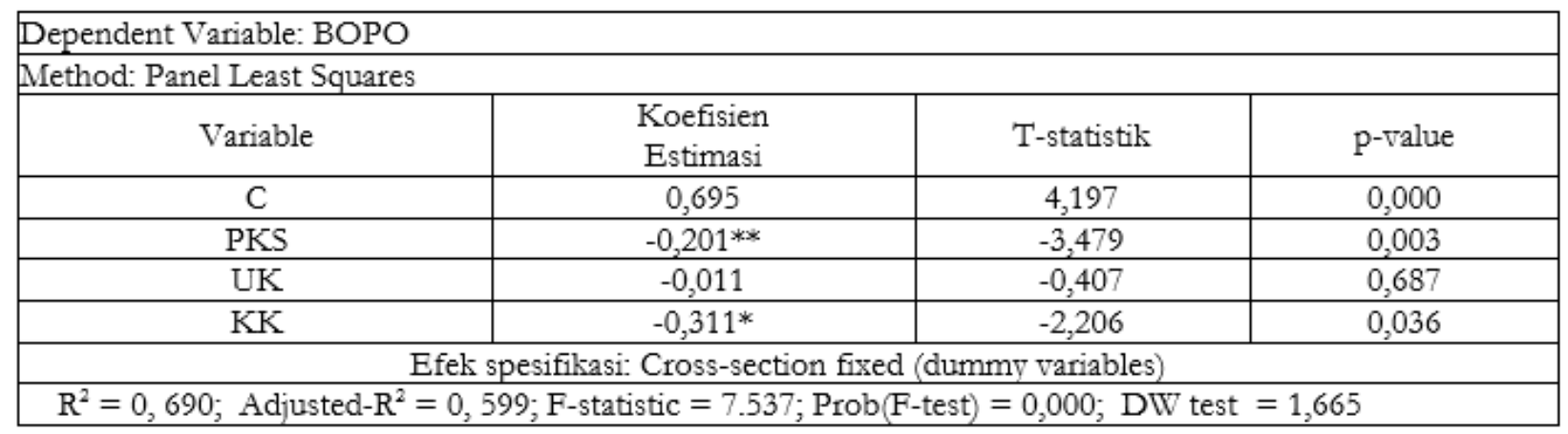

Sumber: Data Sekunder (Diolah), 2020.

* signifikan pada keyakinan $95 \%$, ** signifikan pada keyakinan $99 \%$

Mengacu pada ringkasan regresi di atas, model regresi panel yang menjelaskan hubungan fungsional antara efisiensi perusahaan perbankan dengan proporsi kepemilikan saham, ukuran komisaris dan komposisi komisaris seperti ditunjukkan dalam persamaan 2 .

$$
\mathrm{BOPO}_{\text {it }}=\begin{gathered}
0,695-0,201 \mathrm{PKS}_{\text {it }}-0,011 \mathrm{UK}_{\text {it }}- \\
0,311 \mathrm{KK}_{\mathrm{it}}(2)
\end{gathered}
$$

Kepemilikan saham berpengaruh positif terhadap rasio BOPO ditunjukkan oleh koefisien estimasi sebesar 0,274 dan p-value sebesar 0,001 $(<0,05)$. Sebagaimana dijelaskan sebelumnya, perusahaan dengan rasio BOPO semakin meningkat, mengindikasikan bahwa efisiensi perusahaan tersebut menurun. Karena itu, adanya pengaruh negatif kepemilikan saham terhadap rasio BOPO menjelaskan bahwa kepemilikan saham berpengaruh positif terhadap efisiensi bank umum. Ketika proporsi kepemilikan saham oleh internal perusahaan meningkat, maka efisiensi perusahaan mengalami peningkatan. Sebaliknya, penurunan proporsi kepemilikan saham berdampak pada penurunan efisiensi. Adanya pengaruh positif dan signifikan kepemilikan saham terhadap efisiensi sejalan dengan hasil kajian Widiarti et al. (2015) yang memberikan bukti empiris bahwa konsentrasi kepemilikan saham oleh pihak internal perusahaan merupakan determinan utama efisiensi pengelolaan perusahaan.
Peningkatan proporsi kepemilikan saham oleh internal mendorong manajemen untuk berupaya meningkatkan efisiensi operasional dengan harapan dapat meningkatkan perolehan laba. Temuan ini juga sejalan dengan hasil penelitian Jiang (2012) pada sejumlah perusahaan perbankan di China yang juga membuktikan adanya pengaruh positif kepemilikan saham terhadap efisiensi dan kinerja perusahaan.

Ukuran komisaris juga berpengaruh positif terhadap efisiensi BUS, ditunjukkan oleh koefisien estimasi variabel tersebut terhadap rasio BOPO sebesar $-0,011$. Namun pengaruh tersebut tidak signifikan dengan $\mathrm{p}$-value sebesar 0,687. Peningkatan jumlah dewan komisaris tidak secara nyata berdampak pada peningkatan efisiensi perusahaan. Artinya, perusahaan dengan anggota dewan komisaris yang lebih sedikit tidak memiliki efisiensi lebih baik dibandingkan dengan perusahaan dengan jumlah komisaris yang lebih banyak. Demikian pula sebaliknya, peningkatan jumlah dewan komisaris juga tidak membuat pengelolaan perusahaan menjadi lebih efisien. Tidak adanya pengaruh dewan komisaris terhadap efisiensi BUS bertolak belakang dengan kajian Adnan et al. (2011) yang menyajikan bukti empiris bahwa hubungan antara kedua variabel tersebut adalah positif dan signifikan.

Komposisi dewan komisaris secara positif dan signifikan berpengaruh terhadap efisiensi BUS dengan koefisien estimasi variabel tersebut terhadap rasio BOPO sebesar -0,311 degan $\mathrm{p}$ value sebesar 0,036. Komposisi dewan komisaris diukur berdasarkan persentase komisaris independen terhadap total anggota dewan komisaris. Meningkatnya persentase komisaris 
independen dalam suatu perusahaan berdampak signifikan terhadap peningkatan efisiensi. Sebaliknya, penurunan proporsi komisaris independen berdampak pada penurunan efisiensi operasional BUS. Temuan ini sejalan dengan hasil kajian Tanna et al. (2011) yang juga menyimpulkan bahwa keberadaan komisaris independen dalam suatu perusahaan dapat mendorong efisiensi operasional perusahaan. Hal ini disebabkan, eksistensi komisaris independen dalam mengawasi jalannya kegiatan operasional perusahaan mendorong jajaran manajemen untuk lebih teliti dalam mengalokasikan biaya operasional perusahaan. Hasil penelitian Bozec \& Dia (2005) juga menegaskan peran komisaris independen sebagai salah satu determinan utama jajaran manajemen dalam menjalankan tugasnya secara baik, terutama berkaitan dengan pengalokasian biaya operasional perusahaan.

\section{Simpulan}

Penelitian ini menelaah keterkaitan antara efisiensi operasional dengan implementasi prinsip-prinsip GCG pada Bank Umum Syariah (BUS) di Indonesia. Efisiensi operasional didasarkan pada rasio biaya operasional terhadap pendapatan operasional. Sampel penelitian adalah BUS yang listing di bursa efek Indonesia selama periode 2014-2018. Implementasi GCG dalam hal ini dibatasi pada tiga dimensi yakni kepemilikan saham perusahaan, ukuran komisaris dan komposisi dewan komisaris. Penelitian memberikan bukti empiris bahwa secara simultan ketiga variabel tersebut berpengaruh positif dan signifikan terhadap efisiensi BUS. Secara parsial, kepemilikan saham oleh perusahaan dan komposisi dewan komisaris berpengaruh signifikan terhadap efisiensi BUS. Sebaliknya ukuran dewan komisaris secara parsial tidak berpengaruh signifikan.

Mengacu pada kesimpulan tersebut, maka penelitian ini memiliki implikasi teoritis bahwa upaya peningkatan efisiensi BUS dapat dilakukan dengan melakukan intervensi kebijakan yang berkaitan dengan proporsi kepemilikan saham dan peningkatan jumlah komisaris independen.

\section{Ucapan Terima Kasih}

Kami sebagai peneliti mengucapkan terima kasih yang sebesar-besarnya kepada Ditjen Penguatan Riset dan Pengembangan Kementerian Riset, Teknologi dan Pendidikan Tinggi sebagai penyandang dana penelitian pada skema Penelitian Dosen Pemula (PDP) tahun 2020, dan tidak lupa pula kepada LP2M AKUBANKNusantara yang telah ikut menfasilitasi kelancaran proses penelitian ini.

\section{Daftar Pustaka}

Adnan, M. A., S. N. N. Htay., H. M. A. Rashid., \& Ahmed, K. M. M. (2011). A Panel Data Analysis on the Relationship between Corporate Governance and Bank Efficiency, Journal of Accounting, Finance and Economics, 1(1),1-15.

Al-Najjar, D. (2015). The Effect of Institutional Ownership on Firm Performance: Evidence from Jordanian Listed Firms, International Journal of Economics and Finance, 7(12), 97-105.

Amri, K. (2014). Infrastruktur transportasi dan kepadatan penduduk dampaknya terhadap pendapatan per kapita: Panel data evidence dari sembilan provinsi di Sumatera, Jurnal Ekonomi Manajemen dan Bisnis 2 (2), 438-450.

Amri, K. (2017). Indek Harga Konsumen dan Belanja Modal terhadap Indek Perilaku Korupsi, SI - MEN (Akuntansi dan Manajemen) 8 (1), 49-65.

Amri, K. (2019). Pengaruh zakat dan kesempatan kerja terhadap tingkat kemiskinan di Aceh, Jurnal Al-Muzara'ah 7 (2), 57-70.

Amri, K. (2020). Kebijakan Fiskal dan Pertumbuhan Ekonomi Daerah: Bukti Data Panel di Indonesia, Al-Masharif: Jurnal Ilmu Ekonomi dan Keislaman 8 (1), $1-18$ 
Bebeji, A., Mohammed, A., \& Tanko, M. (2015). The effect of board size and composition on the financial performance of banks in Nigeria, African Journal of Business Management, 9(16), 590-598.

Boone, N., Colombage, S., \& Gunasekarage, A. (2011). Block shareholder identity and firm performance in New Zealand. Pacific Accounting Review, 23(2), 185210.

Bozec, R., \& Dia, M.(2015).Board structure and firm technical efficiency: Evidence from Canadian state-owned enterprises, Pacific-Basic Finance Journal,13(4), 635651.

De Haan, J., \& Vlahu, R. (2015). Corporate governance of banks: A survey. Journal of Economic Surveys, 30(2), 228-277. doi:10.1111/joes.12101.

Garcia-Meca, E., \&Sa'nchez-Ballesta, J. P. (2011). Firm value and ownership structure in the Spanish capital market. Corporate Governance, 11(1), 41-53.

Hsu, W.-Y., \& Petchsakulwong, P. (2010). The Impact of Corporate Governance on the Efficiency Performance of the Thai NonLife Insurance Industry. The Geneva Papers on Risk and Insurance - Issues and Practice, 35(S1), S28-S49. doi:10.1057/gpp.2010.30

Ikhsan, Fitri, C. D., Maulana, H., \& Amri, K. (2020). Effect of inflation on total deposits and financing of sharia commercial banks: A monthly data evidence from Indonesia, Regional Science Inquiry 12 (1), 103-114.

Jiang, C., Feng, G., \& Zhang, J. (2012). Corporate governance and bank performance in China. Journal of Chinese Economic and Business Studies, 10(2), 131-146.

doi:10.1080/14765284.2012.673779
Jiang, H., Habib, A., \&Smallman, C. (2009). The effect of ownership concentration on CEO compensation-firm performance relationship in New Zealand. Pacific Accounting Review, 21(2), 104-131.

Klein, A. (2008). Firm performance and board committee structure. Journal of Law and Economics, 41, 137-165.

Krivogorsky, V . (2016). Ownership, board structure, and performance in continental Europe', The International Journal of Accounting, 41(2), 176-197.

Muliadi, \& Amri, K. (2019a). Infrastruktur jalan, belanja modal dan kesempatan kerja: Bukti data panel kabupaten kota di Aceh, Jurnal Manajemen dan Sains 4 (2), 334341.

Muliadi, \& Amri, K. (2019b). Penerimaan zakat dan penurunan kemiskinan di Aceh: Peran dana otonomi khusus sebagai pemoderasi, Jurnal Ilmiah Ekonomi Islam, 5(3), 231244.

Perrini, F., Rossi, G., \& Rovetta, B. (2008). Does ownership structure affect performance? Evidence from the Italian market. Corporate Governance: An International Review, 16(4), pp.312-325.

Rebeiz, KS \& Salameh, Z. (2016). Relationship between governance structure and financial performance in construction, Journal of Management in Engineering, 22(1), 20-26.

Silva, F., \& Majluf, N. (2018). Does family ownership shape performance outcomes. Journal of Business Research, 61,609-614.

Tanna, S., Pasiouras, F., \& Nnadi, M. (2011). The effect of board size and composition on the efficiency of UK banks. International Journal of the Economics of Business, 18 (3), 441-462. 
Widiarti, A., Siregar, H., \& Andati, T. (2015). The determinants of bank's efficiency in Indonesia. Buletin Ekonomi Moneter Dan Perbankan, 18(2), 129-156. https://doi.org/10.21098/bemp.v18i2.5 20.

Yamori, N., Harimaya, K., \& Tomimura, K. (2017). Corporate governance structure and efficiencies of cooperative banks. International Journal of Finance \& Economics, 22(4), 368-378. doi:10.1002/ijfe.1593.

Zelenyuk, V., \& Zheka, V. (2006). Corporate Governance and Firm's Efficiency: The Case of a Transitional Country, Ukraine. Journal of Productivity Analysis, 25(1-2), 143-157. doi:10.1007/s11123-006-71368. 